\title{
HANGULATKIFEJEZÉS FUZZY INTERPOLÁCIÓ ALAPÚ VISELKEDÉSLEÍRÁSSAL
}

\author{
Gőz Franciska Noémi \\ BSc hallgató, Miskolci Egyetem, Informatikai Intézet, Általános Informatikai Intézeti Tanszék \\ 3515 Miskolc, Miskolc-Egyetemváros,e-mail:goz@iit.uni-miskolc.hu

\section{Bartók Roland} \\ tanársegéd, Automatizálási és Infokommunikációs Intézet \\ 3515 Miskolc, Miskolc-Egyetemváros, e-mail: qgeroli5@uni-miskolc.hu
}

\begin{abstract}
Absztrakt
A szociális robotok feladata, hogy közvetlen kapcsolatban álljanak az emberekkel, az emberek akár társként tekinthessenek rájuk. Ennek megfelelöen a kezelésük egyszerü, nem szükséges magas szintü müszaki ismeret. A robot a saját állapotát egyszerü, elöre meghatározott hangulatokkal közvetitheti a környezete felé, például egyszerü rajzolt arcok segitségével. Ezáltal közvetlenebb, barátságosabb lehet a környezete számára. Olyan helyeken is megjelenhet egy társrobot, mint az idösgondozás vagy intézetek portái.
\end{abstract}

Kulcsszavak: fuzzy, robotika, etorobotika

\section{Abstract}

The task of social robots is to be in direct contact with humans, so that people can even see them as companions. Accordingly, their use is simple, no high level of technical knowledge is required. The robot can convey its own state to its environment in simple, predefined moods, such as simple drawn faces. This can make the robot more direct, friendlier to people. A co-robot can also appear in places such as the receptions of care homes or institutions.

Keywords: fuzzy, robotics, ethorobotics

\section{Bevezetés}

A robotika trendjei változnak, mivel a szolgáltató robotok egyre nagyobb teret nyernek és a mindennapi élet részévé válnak. A szolgálati vagy szociális robotoknak kevésbé ellenőrzött és dinamikusabban változó környezetben kell múködniük, mint az ipari robotoknak, valamint a szociális robotok felhasználói technológiai szempontból kevésbé írástudók, mint az ipari robotok felhasználói, ezért a szociális robotoknak képeseknek kell lenniük arra, hogy természetesen tudjanak kapcsolatba lépni az emberekkel, és bele tudjanak illeszkedni az emberi társadalmi környezetbe. A szociális robotika új kihívásokkal néz szembe, amelyek interdiszciplináris megközelítést igényelnek. A korábbi megközelítésekkel ellentétben, ahol a szociális robotok kommunikációja és viselkedése az ember és ember közötti interakcióin alapult, az etorobotika új irányt kínál.

Ma a robotika még nem elég fejlett ahhoz, hogy elérje az emberek fizikai és kognitív képességeit minden tekintetben, így az ember-állat interakció jobb modellként szolgálhat a szociális robotok viselkedésének megtervezéséhez. Az ember-robot interakció (Human-Robot Interaction: HRI) kezelésének 
egyik módja azon a koncepción alapszik, hogy a robot állatként viselkedő társa az embernek. E paradigma szerint a robotot nem szabad úgy formálni, hogy élethüen hasonlítson valamilyen élölényre. Az ember-gép interakció viszont kövesse a fajok közötti szokásos sémákat, például ember-kutya interakció. Ennek a megközelítésnek egyik jó oka a HRI-ben a „borzongás völgye” [1,2] hatásának hiánya, vagyis minél kevésbé hasonlít egy robot valamilyen élőlényre annál kevésbé vált ki félelmet vagy undort az emberekben.

Az ember-kutya kapcsolat jó példa, mivel a kutyák hasonló szerepet töltenek be, mint a szociális robotok fognak majd a jövőben. A kutyák társakká váltak és olyan kognitív képességeket szereztek a háziasítás során, amelyek fokozzák az emberekkel való fajok közötti kapcsolatot és segítik őket az interakciókban.

Az etorobotikai kutatások etológiai elveket és módszereket alkalmaznak komplex viselkedési modellek levezetésére, amelyek átírhatók matematikai formába és implementálhatóak robotokra. Emberrobot interakciós vizsgálatokat lehet végezni, hogy értékeljék és finomítsák az implementált modelleket. Az etorobotikai kutatásokat használták már arra, hogy viselkedési modelleket hozzanak létre a kötődésről és az ember-robot közötti interakciókról.

A Fuzzy Szabály Interpolációs (FRI - Fuzzy Rule Interpolation) módszerek alkalmazása jól illeszkedik a létező leíró verbális etológiai modellek fogalmilag „tartalék szabályokon alapuló” struktúrájához, a leíró verbális etológiai modellek közül a szabályalap „teljessége” nem szükséges. Fő előnye az FRI módszer adaptációjának az etológiai modell megvalósításában az, hogy egyszerü szabályalapú tudással rendelkező ábrázolási formátum. Emiatt, még a modell numerikus optimalizálása után is, a szabályok továbbra is olvashatók az emberek számára, és segíti a modell etológiai szakértők általi hivatalos érvényesítését. A másik oldalon az FRI miatt alapvetően még mindig alacsony a számítási igénye a modellnek, és közvetlenül megfelel a beágyazott implementációk követelményeinek [3,4].

\section{A FIVE módszer}

A fuzzy logika a fizikai mennyiségek leírásának egyik módja olyan halmazok segítségével, amelyek között megengedett az átmenet, nem éles váltás van a halmazok között. Azok a folyamatok, amelyek túl bonyolultak ahhoz, hogy leírják őket matematikai egyenletekkel, fuzzy szabályokkal írhatók le. A fuzzy szabályok „HA... AKKOR...” felépítésű mondatok, implikációk. Ezek a szabályok a tudásbázis alapjai. A bonyolult funkciókat sok szabállyal lehet megközelíteni.

A szabály bemeneti adatait antecedenseknek, előzményeknek nevezzük, a kimenetet pedig következménynek, konzekvenseknek nevezzük. A klasszikus fuzzy logikában meg kell határozni a bemeneti változók összes lehetséges kombinációit szabály szerint.

A teljes szabályalap hatalmas számú szabályt generál, ezért nagy tárhelyre és nagy számítási teljesítményre van szüksége. A szabályok száma a feladat bonyolultságától függ. Abban az esetben, ha nem minden lehetséges szabályt adunk meg, a szabálybázist ritkának vagy nem teljesnek nevezzük. Ebben az esetben vannak olyan megfigyelések, amelyekhez nem tartozik a szabály, és nincs következtetés a megfigyelésre. Ebben az esetben nem meghatározott állapot keletkezik.

A Fuzzy Szabály Interpolációs (FRI - Fuzzy Rule Interpolation) módszerek segítenek csökkenteni a szabálybázis méretét. Az interpoláció miatt csak a fontos szabályok vannak meghatározva. A FIVE (Fuzzy Interpolation in Vague Environment) módszer alkalmazásorientált egyszerü módszer, mely Shepard interpolációt használ hasonló szabályok között. A hasonlóság a szabály pontjai közötti távolságon alapul. A FIVE módszer kiküszöböli a fuzzyfikáció és defuzzyfikáció müveleteket [3-5]. 
A FIVE FRI módszer a homályos környezet koncepcióján alapszik. A homályos környezet gondolatát alkalmazva a fuzzy partíciókat skálafüggvényekkel lehet leírni és a fuzzy szabály helyettesíthető klasszikus interpolációval. A homályos környezet koncepciója a figyelembe vett elemek hasonlóságán vagy megkülönböztethetetlenségén alapul. Két érték homályos környezetben $\varepsilon$-megkülönböztethetö, ha azok távolsága nagyobb, mint $\varepsilon$.

Az FIVE FRI módszer alapgondolatai összefoglalhatók a következőképpen [6]:

- Ha egy fuzzy partíció homályos környezet (a skálafüggvény vagy a becsült skálafüggvény) létezik, a fuzzy taghalmazai a partíció pontjai alapján jellemezhetők abban a homályos környezetben. Ezek a pontok jelzik a fuzzy kifejezések magját, míg a tagságfüggvényt maga a skálafüggvény írja le.

- Ha a szabálybázisok antecedens és konzekvens univerzumai léteznek a homályos környezetben, minden elsődleges fuzzy halmaz (nyelvi elemek), ami a szabálybázishoz kapcsolódik leírható a homályos környezet pontpárjaival. Így a fuzzy döntés klasszikus interpolációs problémaként kezelhetö.

- A homályos környezet megoldását alkalmazva, amely a pontok súlyozott távolságát jelenti, bármilyen interpoláció, extrapoláció vagy regresszió használható egy fuzzy döntés közelítésére.

\subsection{A viselkedés leíró nyelv}

A FIVE módszer könnyü használatához létezik egy fuzzy viselkedés leíró nyelv (FBDL - Fuzzy Behavior Description Language), amely etológiai viselkedésmodellek nyelvezetéhez igazodik [7].

Az alábbi kulcsszavakból épül fel:

- universe: az antecedenseket és konzekvenseket összefogó nyelvi elemeket és értékeket tartalmazza. Gyakorlatban ezek a bemeneti és kimeneti értékek.

- rulebase: a szabálybázis alkotására használható kulcsszó, nyelvi elemként a konzekvens nevét kell megadni a paraméterében. Ez a kulcsszó fogja össze a szabályokat.

- rule, when, is, and, end: szabály alkotására szolgáló kulcsszavak:

rule „konzekvens nyelvi érétke” when ,antecedens neve” is ,antecedens nyelvi értéke” end.

$\mathrm{Az}$ and kulcsszó az antecedensek összefüzésre szolgál.

\section{ROS}

A ROS (Robot Operating System) egy olyan keretrendszer, amelyet széles körben elfogadnak és használnak a robotrendszer-fejlesztők körében, amely a kutatóktól kezdve a kereskedelmi robotok profi fejlesztőjéig terjed. Eszközök, könyvtárak és konvenciók gyüjteménye, amelynek célja, hogy egyszerüsítse a komplex és robusztus robot viselkedés kialakításának feladatát a robotplatformok sokféleségén keresztül. Az ROS-t eredetileg 2007-ben a Stanford Mesterséges Intelligencia Laboratórium (SAIL) indította el Switch Yard néven, a Stanford AI Robot projekt támogatásaként $[8,9]$.

A hangulatot kifejező egyszerü arcképeket a ROS rendszer részeként egy csomópont (node) formájában valósulnak meg. A csomópont FBDL támogatását a FRIBE Python nyelvủ csomag valósítja meg [10], amely képes közvetlenül az FBDL nyelven írt szabálybázisok értelmezésére és számítására.

\section{Hangulatok megvalósítása}

A robot különböző arckifejezéseivel tudja a környezete felé jelezni az aktuális hangulatát. Ilyenek például a vidám, szomorú, unott, derüs alaphangulatok. Az állapotok között tetszőleges átmenetekre 
A fenti szabályok alapján a robot vidám arcot vesz fel, amikor fel van töltve és embereket érzékel maga körül. A szabályok bemeneteiként szereplő elnevezések az alábbi fogalmakat, megfigyeléseket jelentik:

- battery: Az akkumulátor töltöttsége. Fontos tényező a robot szempontjából, hogy további viselkedésminták a robotot az energiaszint csökkenésekor a töltő felé irányítják.

- soundlevel: a környezet zajszintje, amelyet mikrofonokkal érzékel.

- distance: az emberek távolsága a robottól a környezetében.

- speed: a robot mozgási sebessége.

Kimenetként jelennek meg az alábbi paraméterek:

- eye: a kirajzolt szem formája.

- mouth: a kirajzolt száj formája.

A grafikus felület az alábbi alapul szolgáló arcokat képes megjeleníteni:1. ábra. Az egyes állapotok közötti átmenetet a FIVE interpolációs módszer által generált kimeneti érték adja meg. Az így előállt hangulati értékeket nem csak az arcot kirajzoló modul, hanem a robot más moduljai is felhasználják, így például befolyásolja a roboton elhelyezett többszínü világítás színezetét.
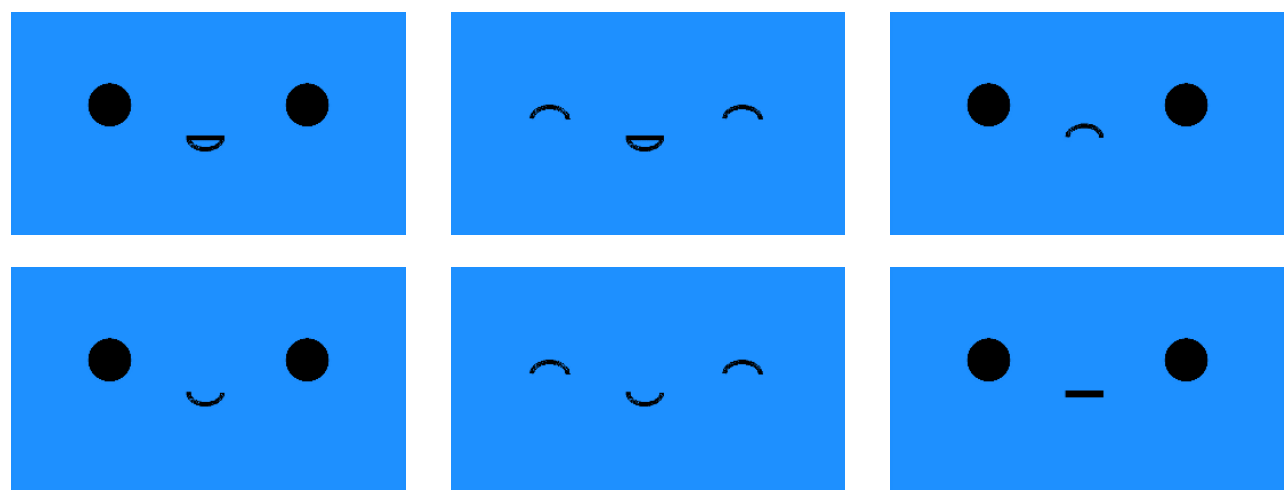

1. ábra Lehetséges hangulatot kifejező állapotok

A felvázolt arcok a robot tetején elhelyezett kijelzőn jelennek meg, amelynek pozíciója megfelel annak, mintha ténylegesen a robot feje, illetve arca lenne.

\section{5. Összefoglalás}

A cikkben egy viselkedés alapú robot számára készült hangulat kifejező grafikus felület került bemutatásra. A robot alapvető feladata, hogy emberek között képes legyen mozogni és az emberekkel kapcsolatba lépni. Az épületen belül megmutatni az érdeklődőknek a dolgozók szobájának helyét vagy az adott személy ajtajához vezetni őket. A robot mozgását, viselkedését és a hangulatát kifejező grafikai elemek müködését fuzzy alapú viselkedés leírás irányítja, amely reagál a környezet változásaira és a robot belső, mérhető paramétereire. A hangulatot a roboton elhelyezett képernyőre rajzolt egyszerü arc segítségével közvetíti a külvilág felé néhány alaphangulaton és ezek tetszőleges keverékén keresztül. 


\section{Köszönetnyilvánítás}

A cikkben ismertetett kutató munka az EFOP-3.6.1-16-2016-00011 jelü „Fiatalodó és Megújuló Egyetem - Innovatív Tudásváros - a Miskolci Egyetem intelligens szakosodást szolgáló intézményi fejlesztése" projekt részeként - a Széchenyi 2020 keretében - az Európai Unió támogatásával, az Európai Szociális Alap társfinanszírozásával valósul meg.

\section{Irodalom}

[1] Mori, M. The Uncanny Valley. Energy, 1970, 7(4):33-35

[2] Mori, M., MacDorman, K., Kageki, N. The Uncanny Valley [From the Field]. IEEE Robotics \& Automation Magazine 2012, 19(2):98-100. https://doi.org/10.1109/MRA.2012.2192811

[3] Korondi, P., Korcsok, B., Kovács, S., Niitsuma, M. Etho-robotics: What kind of behaviour can we learn from the animals? IFAC-Papers Online 2015, 48(19):244-255.

https://doi.org/10.1016/j.ifacol.2015.12.041

[4] Kovács, S., Vincze, D., Gácsi, M., Korondi, P. Interpolation based fuzzy automaton for humanrobot interaction. IFAC Proceedings Volumes 2009, 42(16):317-322.

https://doi.org/10.3182/20090909-4-JP-2010.00055

[5] Bartók, R., Vásárhelyi, J. Two methods for autonomous robot obstacle sensing and application programming interface for fuzzy rule interpolation. In 2017 18th Interna-tional Carpathian Control Conference (ICCC) (pp. 87-92). IEEE. https://doi.org/10.1109/CarpathianCC.2017.7970376

[6] Kovács, S. Extending the fuzzy rule interpolation" FIVE" by fuzzy observation. In Computational Intelligence, Theory and Applications (pp. 485-497). Springer, Berlin, Heidel-berg. Field]. IEEE Robotics \& Automation Magazine 2006, 19:98-100. https://doi.org/10.1007/3-540-34783-6_48

[7] Piller, I., Kovács, Sz. Fuzzy Behavior Description Language: A Declarative Language for Interpolative Behavior Modeling. Acta Polytechnica Hungarica 2019, 16(9):47-72. https://doi.org/10.12700/APH.16.9.2019.9.4

[8] Bipin, K. Robot Operating System Cookbook: Over 70 Recipes to Help You Master Advanced ROS Concepts. Packt Publishing Limited, 2018.

[9] ROS weboldala: https://www.ros.org/about-ros/ Accessed: 10/11/2020

[10] FRIBE: https://github.com/piller-imre/fribe-python Accessed: 10/11/2020 